\title{
Aspects of globalization of employment in the European Union
}

\author{
Petrică Sorin Angheluță ${ }^{1, *}$, Svetlana Platagea Gombos ${ }^{2}$, Ciprian Rotaru ${ }^{2}$, and Anna Kant ${ }^{3}$ \\ ${ }^{1} \mathrm{PhD}$, Bucharest University of Economic Studies \\ ${ }^{2} \mathrm{PhD}$ Student, Bucharest University of Economic Studies \\ ${ }^{3} \mathrm{PhD}$ Student, Valahia University of Targoviste
}

\begin{abstract}
Research background: The influence exerted by globalization manifests predominantly in field of employment. The challenges generated by this process are amplified by technological developments. Facilities of movement and establishment in various regions, and the new opportunities for conducting professional activities, have led to increased mobility of employment. Globalization has led to a growing interest of businesses to operate outside their own country.

Purpose of the article: In the current context, the purpose of the article is to analyze whether in the field of employment there is a tendency to increase the share of persons employed in enterprises controlled from outside the EU in total EU employment.

Methods: The article presents the comparative situation of the number of persons employed for enterprises controlled from outside the EU. The article also presents an analysis of the number of persons employed for enterprises controlled from inside the European Union.

Findings \& Value added: Following the analysis, there is an increase in employment in enterprises controlled from inside the EU in total EU employment. Also, depending on the economic activity, there is a higher distribution for the following economic activities: Manufacturing, Wholesale and retail trade, Administrative and support service activities, Information and communication, Transportation and storage. Regarding the comparative situation of the number of employed persons for enterprises controlled by all countries of the world for total business economy, except financial and insurance activities, a number of over 5 million employed persons was registered in 6 countries (Germany, France, Italy, Spain, Poland, Netherlands). Regarding the situation of the foreign control of enterprises by economic activity, controlled by all countries of the world for total business economy, except financial and insurance activities, at the level of the European Union the economic activities in which more than 10 million people are employed are: Manufacturing, Wholesale and retail trade, Administrative and support service activities, Construction, Professional, scientific and technical activities, Accommodation and food service activities and Transportation and storage.
\end{abstract}

\footnotetext{
* Corresponding author: sorin.angheluta@gmail.com
} 
Keywords: European Union; Employment; Globalization

JEL Classification: $J 21 ; F 6$; J6

\section{Introduction}

The economic growth of a less developed state is influenced by the existence of capital flows. Thus, through the proposed measures, it is considered that development and economic growth strategies can contribute to attracting these capital flows (Arora, 2009).

In the context of globalization, in order to optimize efficiency, the level of qualification of employees can influence the degree to which product quality is ensured (Thamm et al., 2020).

The transmission of new technologies is greatly facilitated by multinational enterprises, which, through the cross-border investments they make, contribute to the creation of new jobs (Patala et al., 2021).

Given the new technologies, the increase in the level of competitiveness required in the labor market has led to an increased awareness of the process of acquiring professional and personal skills (Burlacu et al., 2019). Thus, the recognition of qualifications is becoming increasingly important for both employees and employers (Pauletto, 2021).

With the development of technologies, the needs and desires of consumers have increased. Based on the continuous increase of consumption, production also increased (Panizzut et al., 2021).

For any community, economic development is influenced by socio-economic aspects (Androniceanu et al., 2017). In the context of globalization, the evidence of these challenges is growing. Increasing the number of employees abroad was possible by opening up the labor market. Thus, competitiveness increased, and new jobs could be created (Šoltés et al., 2021).

It is considered that economic development will depend on the degree to which globalization will materialize (Leal et al., 2021). For this reason, the importance of foreign direct investment is increasing.

The relocation of industries that pollute the environment in developing countries can affect the state of the environment in these countries. However, the transfer of green technologies can mitigate environmental degradation (Bran et al., 2018). It is also found that even the development of energy scenarios must consider the process of globalization (Baard, 2021).

It is found that states that are on a higher stage of development have managed to attract larger funds from foreign investors. Often, through regulatory requirements, competition from foreign companies with companies in a country turns into investments to support domestic affairs (Bodislav et al., 2020). The intention to invest in a country is influenced by the antitrust rules of that country (Clougherty and Zhang, 2021).

Against the background of urban developments, new jobs will be able to be set up in rural areas. This aspect is based on the growing demands for food, building materials, energy (Schmidt et al., 2021).

Education is one of those social indicators that allows the measurement of quality of life (Stofkova, 2021). Thus, we can say that in order to improve our quality of life, it is necessary to apply certain measures that lead to an increase in the level of education. However, it is found that the selection of staff according to qualification leads to small differences in qualification within a company. At the same time, this selection based on 
qualification may lead to greater differences in qualification between firms (Håkanson et al., 2021).

Within a society, over time, various changes of an economic, social, cultural nature can take place (Burlacu et al., 2020). All this, together with demographic and technological changes, lead to the need for new skills and knowledge, to the idea of applying new forms of learning (Elshafie, 2021).

It is believed that sustainable development goals can be achieved by improving connectivity between countries (Profiroiu et al., 2020). In the context of globalization, its multiple dimensions must not negatively influence the environment, so that the benefits can be accumulated in support of society (Becker et al., 2021). Further progress can be manifested by increasing the degree of integration of strategic resources (D'Oria et al., 2021).

\section{Methods}

The influence exerted by globalization manifests predominantly in field of employment. The challenges generated by this process are amplified by technological developments. Facilities of movement and establishment in various regions, and the new opportunities for conducting professional activities, have led to increased mobility of employment. Globalization has led to a growing interest of businesses to operate outside their own country.

In the current context, the purpose of the article is to analyze whether in the field of employment there is a tendency to increase the share of persons employed in enterprises controlled from outside the EU in total EU employment.

The article presents the comparative situation of the number of persons employed for enterprises controlled from outside the EU. The article also presents an analysis of the number of persons employed for enterprises controlled from inside the European Union.

Following the analysis, there is an increase in employment in enterprises controlled from inside the EU in total EU employment. Also, depending on the economic activity, there is a higher distribution for the following economic activities: Manufacturing, Wholesale and retail trade, Administrative and support service activities, Information and communication, Transportation and storage.

\section{Results and Discussions}

In recent years, cross-border opportunities have increased. This has been strengthened by ecommerce and digital technologies. European companies' access to new large markets has increased. Also, a major source for the economic growth of a region is foreign investment (EC, 2017).

Table 1 presents the comparative situation of the number of persons employed for controlling entities is from inside the EU.

For 2018, it is observed that the number of employed persons is approximately 13 million. For the existing data on the EUROSTAT website, compared to 2014, in 2018 there are decreases for Belgium (from 296735 to 295758 persons employed). The other countries record increases in the values of persons employed for controlling entities is from inside the EU.

Table 1. The comparative situation of the number of persons employed for controlling entities is from inside the EU

\begin{tabular}{|c|c|c|c|}
\hline Countries & $\mathbf{2 0 1 4}$ & $\mathbf{2 0 1 6}$ & $\mathbf{2 0 1 8}$ \\
\hline European Union & $:$ & $:$ & 12.985 .322 \\
\hline
\end{tabular}




\begin{tabular}{|c|c|c|c|}
\hline Countries & 2014 & 2016 & 2018 \\
\hline Belgium & 296.735 & 258.724 & 295.758 \\
\hline Bulgaria & 219.562 & 217.477 & 232.113 \\
\hline Czechia & 684.189 & 733.293 & 751.308 \\
\hline Denmark & 213.599 & 233.465 & 251.779 \\
\hline Germany & 1.809 .736 & 1.796 .834 & 2.070 .866 \\
\hline Estonia & 73.171 & 73.951 & 75.315 \\
\hline Ireland & 125.691 & 142.781 & 186.152 \\
\hline Greece & 88.482 & 107.099 & $:$ \\
\hline Spain & 956.400 & 1.059 .068 & 1.177 .882 \\
\hline France & 1.058 .598 & 1.104 .941 & $:$ \\
\hline Croatia & 110.886 & 100.490 & 142.707 \\
\hline Italy & 653.383 & 707.618 & 823.242 \\
\hline Cyprus & 8.545 & 8.871 & 11.230 \\
\hline Latvia & 87.626 & 99.986 & 105.945 \\
\hline Lithuania & 99.001 & 106.459 & 112.957 \\
\hline Luxembourg & 68.758 & 74.426 & 81.236 \\
\hline Hungary & 453.734 & 466.750 & 506.102 \\
\hline Malta & 11.911 & 14.025 & 17.841 \\
\hline Netherlands & 485.184 & 549.401 & 591.723 \\
\hline Austria & 380.901 & 407.646 & 442.493 \\
\hline Poland & 1.107 .530 & 1.239 .217 & 1.456 .166 \\
\hline Portugal & 273.856 & $:$ & $:$ \\
\hline Romania & 817.149 & 833.507 & 875.150 \\
\hline Slovenia & 79.366 & 91.762 & 109.158 \\
\hline Slovakia & 294.568 & 318.331 & 337.094 \\
\hline Finland & 163.650 & 164.689 & 167.876 \\
\hline Sweden & 393.256 & 409.172 & 442.413 \\
\hline
\end{tabular}

The highest increases are observed in: Poland (+348636 persons employed), Germany (+261130 persons employed), Spain (+221482 persons employed).

Table 2. Distribution by economic activity for the number of persons employed for controlling entities is from inside the EU

\begin{tabular}{|c|c|}
\hline Economic activity & Number of persons employed \\
\hline Mining and quarrying & 47641 \\
\hline Manufacturing & 4674427 \\
\hline $\begin{array}{c}\text { Electricity, gas, steam and air conditioning supply } \\
\text { activities }\end{array}$ & 147800 \\
\hline $\begin{array}{c}\text { Construction } \\
\text { Whoter supply; sewerage, waste management and remediation }\end{array}$ & 104759 \\
\hline $\begin{array}{c}\text { Transportation and storage } \\
\text { molesale and retail trade; repair of motor vehicles and }\end{array}$ & 353697 \\
\hline Accommodation and food service activities & 3320000 \\
\hline Information and communication & 731327 \\
\hline Financial and insurance activities & 444612 \\
\hline Real estate activities & 835844 \\
\hline Professional, scientific and technical activities & 476826 \\
\hline Administrative and support service activities & 80000 \\
\hline Repair of computers and personal and household goods & 676545 \\
\hline
\end{tabular}

Also, for 2018, the highest values are registered in Germany (2070866 persons), Poland (1456166 persons), Spain (1177882 persons), Romania (875150 persons), Italy (823242 
persons), Czechia (751308 persons), Netherlands (591723 persons), Hungary (506102 persons).

At the level of the European Union, table 2 presents the situation regarding the foreign control of enterprises by economic activity, for 2018.

From the data presented, for 2018, depending on the economic activity, there is a higher distribution for the following activities: Manufacturing (4674427 persons), Wholesale and retail trade (3320000 persons), Administrative and support service activities (1535224 persons), Information and communication (835844 persons), Transportation and storage (731327 persons), Professional, scientific and technical activities (676545 persons).

Table 3. The comparative situation of the number of persons employed for controlling entities is from inside the EU, for those economic activities which, at European level, have over 500000 persons employed

\begin{tabular}{|c|c|c|c|c|c|c|}
\hline Countries & $\mathbf{1}$ & $\mathbf{2}$ & $\mathbf{3}$ & $\mathbf{4}$ & $\mathbf{5}$ & $\mathbf{6}$ \\
\hline $\begin{array}{c}\text { European } \\
\text { Union }\end{array}$ & 4.674 .427 & 3.320 .000 & 731.327 & 835.844 & 676.545 & 1.535 .224 \\
\hline Belgium & 90.704 & 70.921 & 13.279 & 8.277 & 5.591 & 66.472 \\
\hline Bulgaria & 89.127 & 46.481 & 13.437 & 29.928 & 11.382 & 14.331 \\
\hline Czechia & 390.960 & 156.326 & 37.514 & 26.234 & 29.318 & 51.069 \\
\hline Denmark & 58.210 & 71.797 & 35.678 & 15.064 & 18.212 & 22.529 \\
\hline Germany & 826.401 & 391.347 & 105.142 & 118.320 & 142.150 & 256.465 \\
\hline Estonia & 29.944 & 17.974 & 3.172 & 5.437 & 1.722 & 10.766 \\
\hline Ireland & 29.621 & 66.327 & 10.538 & 16.397 & 14.403 & 27.143 \\
\hline Greece & $:$ & 50.184 & $:$ & 11.789 & 8.939 & $:$ \\
\hline Spain & 323.262 & 329.731 & 56.602 & 90.027 & 75.256 & 188.724 \\
\hline France & 386.167 & 346.962 & $:$ & 72.843 & 64.190 & 230.022 \\
\hline Croatia & 45.506 & 39.654 & 7.707 & 11.697 & 5.892 & 12.254 \\
\hline Italy & 263.839 & 250.803 & 32.689 & 46.969 & 47.304 & 112.931 \\
\hline Cyprus & $:$ & 4.296 & 1.865 & 569 & 327 & 1.969 \\
\hline Latvia & 23.385 & 34.570 & 8.827 & 12.443 & 4.564 & 10.521 \\
\hline Lithuania & 32.550 & 32.258 & 9.929 & 9.431 & 7.079 & 9.081 \\
\hline Luxembourg & $:$ & 16.448 & $:$ & $:$ & $:$ & $:$ \\
\hline Hungary & 245.157 & 106.886 & 28.682 & 30.015 & 25.896 & 31.080 \\
\hline Malta & $:$ & $:$ & $:$ & $:$ & $:$ & $:$ \\
\hline Netherlands & 98.211 & 203.421 & 73.264 & 46.747 & 26.439 & 63.190 \\
\hline Austria & 114.517 & 173.063 & $:$ & 20.812 & 18.262 & 61.963 \\
\hline Poland & 665.526 & 393.237 & 73.104 & 88.542 & 49.234 & 82.362 \\
\hline Portugal & 92.789 & 101.433 & 17.084 & 26.980 & 10.309 & 86.959 \\
\hline Romania & 421.460 & 169.249 & 39.990 & 72.731 & 35.177 & 60.200 \\
\hline Slovenia & 50.690 & 33.336 & 5.548 & 4.138 & 2.437 & 7.619 \\
\hline Slovakia & 182.915 & 64.869 & 19.406 & 20.041 & 10.002 & 15.057 \\
\hline Finland & 46.049 & 40.896 & 11.186 & 13.288 & 13.337 & 18.937 \\
\hline Sweden & 128.676 & 110.944 & 44.524 & 27.664 & 38.240 & 49.575 \\
\hline & & & & & & \\
\hline
\end{tabular}

1 - Manufacturing

2 - Wholesale and retail trade; repair of motor vehicles and motorcycles

3 - Transportation and storage

4 - Information and communication

5 - Professional, scientific and technical activities

6 - Administrative and support service activities 
Given the information in the previous table, Table 3 presents the comparative situation of the number of persons employed for controlling entities is from inside the EU, for those economic activities that, at European level, have over 500000 persons employed.

For manufacturing, the countries where the highest values for employed persons are: Germany (826401 persons), Poland (665526 persons), Romania (421460 persons), Czechia (390960 persons), France (386167 persons), Spain (323262 persons). For wholesale and retail trade; repair of motor vehicles and motorcycles, the highest values are recorded in: Poland (393237 persons), Germany (391347 persons), France (346962 persons), Spain (329731 persons), Italy (2508003 persons), Netherlands (203421 persons). For transportation and storage, values of over 50000 persons employed are observed in: Germany (105142 persons), Netherlands (73264 persons), Poland (73104 persons), Spain (56602 persons). Also, over 50000 employed persons register for information and communication in: Germany (118320 persons), Spain (90027 persons), Poland (88542 persons), France (72843 persons), Romania (72731 persons). For administrative and support service activities, the highest values are in: Germany (256465 persons), France (230022 persons), Spain (188724 persons), Italy (112931 persons).

It is observed that three countries have high values for all economic activities: Germany, France and Spain.

Table 4. The comparative situation of the number of persons employed for enterprises controlled by all countries of the world for total business economy

\begin{tabular}{|c|c|c|c|c|c|c|}
\hline Countries & $\mathbf{2 0 0 8}$ & $\mathbf{2 0 1 0}$ & $\mathbf{2 0 1 2}$ & $\mathbf{2 0 1 4}$ & $\mathbf{2 0 1 6}$ & $\mathbf{2 0 1 8}$ \\
\hline $\begin{array}{c}\text { European } \\
\text { Union }\end{array}$ & $:$ & $:$ & $:$ & $:$ & $:$ & 127.410 .755 \\
\hline Belgium & 2.558 .022 & 2.649 .160 & 2.718 .355 & 2.744 .636 & 2.802 .427 & 2.961 .184 \\
\hline Bulgaria & 2.059 .660 & 1.927 .935 & 1.872 .997 & 1.888 .722 & 1.961 .520 & 2.014 .979 \\
\hline Czechia & 3.653 .435 & 3.446 .754 & 3.521 .517 & 3.515 .084 & 3.661 .872 & 3.778 .328 \\
\hline Denmark & 2.074 .464 & 1.505 .933 & 1.602 .105 & 1.638 .700 & 1.714 .856 & 1.808 .887 \\
\hline Germany & 23.206 .226 & 24.932 .378 & 26.401 .395 & 27.781 .123 & 29.086 .416 & 31.120 .840 \\
\hline Estonia & 279.955 & 220.287 & 235.242 & 241.378 & 246.701 & 251.327 \\
\hline Ireland & 1.262 .385 & 1.080 .859 & 1.097 .445 & 1.240 .689 & 1.381 .788 & 1.504 .484 \\
\hline Greece & $:$ & $:$ & 2.198 .983 & 2.212 .462 & 2.366 .201 & 2.593 .935 \\
\hline Spain & 13.460 .274 & 11.989 .152 & 10.923 .324 & 10.655 .035 & 11.713 .718 & 12.574 .611 \\
\hline France & 15.688 .102 & 15.430 .052 & 16.091 .930 & 16.144 .350 & 16.361 .782 & 17.359 .318 \\
\hline Croatia & $:$ & 1.075 .442 & 1.002 .905 & 999.426 & 997.335 & 1.033 .317 \\
\hline Italy & 15.950 .493 & 15.090 .021 & 14.715 .132 & 14.158 .595 & 14.547 .328 & 15.111 .869 \\
\hline Cyprus & 242.642 & 242.049 & 224.915 & 209.345 & 229.292 & 269.661 \\
\hline Latvia & 677.822 & 540.151 & 573.580 & 619.685 & 634.957 & 658.337 \\
\hline Lithuania & 992.107 & 775.203 & 835.630 & 909.868 & 954.639 & 987.695 \\
\hline Luxembourg & $:$ & 232.228 & 242.533 & 249.348 & 265.037 & 286.339 \\
\hline Hungary & 2.638 .505 & 2.437 .262 & 2.430 .881 & 2.472 .699 & 2.672 .445 & 2.831 .631 \\
\hline Malta & 97.095 & 117.946 & 119.224 & 125.765 & 142.606 & 157.957 \\
\hline Netherlands & 5.578 .876 & 5.317 .258 & 5.359 .441 & 5.327 .401 & 5.598 .996 & 6.002 .103 \\
\hline Austria & 2.588 .941 & 2.557 .287 & 2.671 .477 & 2.720 .484 & 2.778 .445 & 2.927 .624 \\
\hline Poland & 5.453 .568 & 5.347 .289 & 5.294 .758 & 5.356 .464 & 5.633 .885 & 6.474 .657 \\
\hline Portugal & 3.475 .617 & 3.257 .064 & 2.942 .895 & 2.894 .720 & 3.115 .885 & 3.425 .893 \\
\hline Romania & 4.413 .763 & 3.713 .223 & 3.837 .868 & 3.834 .201 & 3.978 .093 & 4.061 .214 \\
\hline Slovenia & 647.795 & 604.720 & 574.479 & 578.976 & 604.234 & 654.747 \\
\hline Slovakia & 1.099 .260 & 1.471 .438 & 1.417 .228 & 1.439 .731 & 1.526 .626 & 1.652 .546 \\
\hline Finland & 1.472 .981 & 1.411 .302 & 1.457 .598 & 1.470 .426 & 1.458 .963 & 1.516 .165 \\
\hline Sweden & 2.961 .030 & 2.897 .601 & 3.025 .006 & 3.043 .722 & 3.203 .909 & 3.391 .107 \\
\hline
\end{tabular}


Table 4 presents the comparative situation of the number of persons employed for enterprises controlled by all countries of the world for total business economy, except financial and insurance activities.

It is noted that, compared to 2008, in 2010, significant decreases in values were observed for: Spain (-1471122 persons), Italy (-860472 persons), Romania (-700540 persons). At the same time, increases were registered in: Germany $(+1726152$ persons), Slovakia ( +372178 persons), Belgium ( +91138 persons).

The evolution for the period 2008-2018 shows a significant increase of persons employed for: Germany (+7914614 persons), France (+1671216 persons), Poland $(+1021089$ persons), Slovakia (+553286 persons), Sweden (+430077 persons), Netherlands (+423227 persons), Belgium (+403162 persons), Greece (+394952 persons).

In 2018, over 5 million people employed for enterprises controlled by all countries of the world were in: Germany (31120840 persons), France (17359318 persons), Italy (15111869 persons), Spain (12574611 persons), Poland (6474657 persons), Netherlands (6002103 persons).

At the level of the European Union, table 5 presents the situation regarding the foreign control of enterprises by economic activity, controlled by all countries of the world for total business economy, except financial and insurance activities, for 2018.

Table 5. The situation regarding the foreign control of enterprises by economic activity, controlled by all countries of the world for total business economy, except financial and insurance activities

\begin{tabular}{|c|c|}
\hline Economic activity & Number of persons employed \\
\hline Mining and quarrying & 408242 \\
\hline Manufacturing & 29472293 \\
\hline $\begin{array}{c}\text { Electricity, gas, steam and air conditioning supply } \\
\text { activities }\end{array}$ & 1300000 \\
\hline $\begin{array}{c}\text { Construction } \\
\text { Water supply; sewerage, waste management and remediation } \\
\text { motorcycles }\end{array}$ & 1500000 \\
\hline $\begin{array}{c}\text { Wransportation and storage } \\
\text { Tccommodation and food service activities }\end{array}$ & 28593025 \\
\hline Information and communication & 10027733 \\
\hline Financial and insurance activities & 10680380 \\
\hline Real estate activities & 6071397 \\
\hline Professional, scientific and technical activities & 2469037 \\
\hline Administrative and support service activities & 2510000 \\
\hline Repair of computers and personal and household goods & 10887765 \\
\hline
\end{tabular}

It is observed that the economic activities in which over 10 million people are employed are: Manufacturing (29472293 persons), Wholesale and retail trade; repair of motor vehicles and motorcycles (28593025 persons), Administrative and support service activities (13852835 persons), Construction (11754151 persons), Professional, scientific and technical activities (10887765 persons), Accommodation and food service activities (10680380 persons) and Transportation and storage (10027733 persons).

\section{Conclusions}

In the context of globalization, due to the intensity and interconnection of risk sources, but also the high number of risk sources, an increasingly complex task for enterprises is their internationalization (Buganová et al., 2021). 
From the analysis performed, it is observed that, compared to 2014 , in 2018 , in all countries there are increases in the values of employees for control entities from within the EU, except Belgium. In 2018, over 500000 employed persons were in: Germany, Poland, Spain, Romania, Italy, Czechia, Netherlands, Hungary.

For 2018, depending on the economic activity, there is a higher distribution for the following activities: Manufacturing, Wholesale and retail trade, Administrative and support service activities, Information and communication, Transportation and storage, Professional, scientific and technical activities.

Also, in 2018, over 5 million people employed for enterprises controlled by all countries of the world were in: Germany, France, Italy, Spain, Poland, Netherlands.

Advancing emerging economies in the value chain will lead to increased competition. Reducing the gap between the least technologically advanced and the most advanced regions can be achieved by acquiring by employees those appropriate skills, respectively by investing in education. At the same time, a new cultural identity can be determined by the emphasis on exports and, implicitly, on the higher remuneration of work in this sector (Bonomi et al., 2021).

\section{References}

1. Androniceanu, A., Burlacu, S., Drăgulănescu, I. V., \& Nicolae, E. E. (2017). New trends of businesses digitalization in Romania and the behaviour young consumers. BASIQ International Conference: New Trends in Sustainable Business and Consumption, 31, 27-35.

2. Arora, R.U. (2009). Globalization and stages of development: An exploratory analysis. Review of Urban \& Regional Development Studies, 21(2/3).

3. Baard, P. (2021). Knowledge, participation, and the future: Epistemic quality in energy scenario construction. Energy Research \& Social Science, 75, 102019.

4. Becker, W., Domínguez-Torreiro, M., Neves, A.R., Moura, C.T., \& Saisana, M. (2021). Exploring the link between Asia and Europe connectivity and sustainable development. Research in Globalization, 3, 100045.

5. Bodislav, D. A., Buzoianu, O. A. C., Burlacu, S., \& Rădulescu, C. V. (2020). Analysis of companies in Romania from the perspective of risk perception and the management needs thereof. Economic Convergence in European Union, 341.

6. Bonomi, G., Gennaioli, N., \& Tabellini, G. (2021). Identity, beliefs, and political conflict. The Quarterly Journal of Economics, 136(4), 2371-2411.

7. Bran, F.., Alpopi, C., \& Burlacu, S. (2018). Territorial development-disparities between the developed and the least developed areas of Romania. LUMEN Proceedings, 6(1), 146-155.

8. Buganová, K., Šimíčková, J., \& Brutovský, M. (2021). Impact of global changes in the business environment in relation to risk management. SHS Web of Conferences, 92, 03004.

9. Burlacu, S., Alpopi, C., Mitrită, M., \& Popescu, M. L. (2019). Sustainable egovernance and human resource development. European Journal of Sustainable Development, 8(5), 16.

10. Burlacu, S., Gavrilă, A., Popescu, I. M., Gombos, S. P., \& Vasilache, P. C. (2020). Theories and models of functional zoning in urban space. Revista de Management Comparat International, 21(1), 44-53. 
11. Clougherty, J.A., \& Zhang, N. (2021). Foreign investor reactions to risk and uncertainty in antitrust: U.S. merger policy investigations and the deterrence of foreign acquirer presence. Journal of International Business Studies, 52, 454-478.

12. Elshafie, E. M. (2018). Toward a knowledge-based economy. Learning university is a key prerequisite. Journal of International Business Research, 17(1), 1-20.

13. European Commission (2017). Reflection paper on harnessing globalization.

14. EUROSTAT (2021). Retrieved from: https://ec.europa.eu/eurostat/data/statistics-a$\mathrm{z} / \mathrm{abc}$.

15. Håkanson, C., Lindqvist, E., \& Vlachos, J. (2021). Firms and skills: The evolution of worker sorting. The Journal of Human Resources, 56(2), 51-538.

16. Leal, P.H., Caetano, R.V., \& Marques, A.C. (2021). Is the relocation of polluting industries prompted by FDI flow and stock, globalisation, corruption and regulation? International Journal of Environmental Research and Public Health, 18, 1981.

17. D’Oria, L., Crook, T.R., Ketchen, Jr., D.J., Sirmon, D.G., \& Wright, M. (2021). The evolution of resource-based inquiry: A review and meta-analytic integration of the strategic resources-actions-performance pathway. Journal of Management, 47(6), 138 -1429 .

18. Panizzut, N., Rafi-ul-Shan, P.M., Amar, H., Sher, F., Mazhar, M.U., \& Kleme, J.J. (2021). Exploring relationship between environmentalism and consumerism in a market economy society: A structured systematic literature review. Cleaner Engineering and Technology, 2, 100047.

19. Patala, S., Juntunen, J.K., Lundan, S., \& Ritvala, T. (2021). Multinational energy utilities in the energy transition: A configurational study of the drivers of FDI in renewables. Journal of International Business Studies, 52, 930-950.

20. Pauletto, C. (2021). Blockchain in international e-government processes: Opportunities for recognition of foreign qualifications. Research in Globalization, 3, 100034.

21. Profiroiu, M. C., Radulescu, C. V., Burlacu, S., \& Guţu, C. (2020). Changes and trends in the development of the world economy. Competitivitatea sii Inovarea in Economia Cunoaşterii (pp. 324-330).

22. Schmidt, W., Commeh, M., Olonade, K., Schiewer, G.L., Dodoo-Arhin, D., Dauda, R., Fataei, S., Tawiah, A.T., Mohamed, F., Thiedeitz, M., Radebe, N.W., \& Rogge, A. (2021). Sustainable circular value chains: From rural waste to feasible urban construction materials solutions. Developments in the Built Environment, 6, 100047.

23. Šoltés, V., Repková Štofková, K., \& Lenko, F. (2021). The impact of foreign workforces on selected aspects of economic development of society. SHS Web of Conferences, 92, 07057.

24. Stofkova, Z., Seemann, P., \& Binasova, V. (2021). Evaluation of quality of life in the period of globalization. SHS Web of Conferences, 92, 02059.

25. Thamm, S., Huebser, L., Adam, T., Hellebrandt, T., Heine, I., Barbalho, S., Velho, S.K., Becker, M., Bagnato, V.S., \& Schmitt, R.H. (2020). Concept for an augmented intelligence-based quality assurance of assembly tasks in global value networks. Procedia CIRP, 97, 423-428. 